\title{
Product Market Evidence on the Employment Effects of the Minimum Wage
}

\author{
Daniel Aaronson, Federal Reserve Bank of Chicago \\ Eric French, Federal Reserve Bank of Chicago
}

We infer the employment response to a minimum wage change by calibrating a model of employment for the restaurant industry. Whereas perfect competition implies that employment falls and prices rise after a minimum wage increase, the monopsony model potentially implies the opposite. We show that estimated price responses are consistent with the competitive model. We place fairly tight bounds on the employment response, with the most plausible parameter values suggesting that a $10 \%$ increase in the minimum wage lowers low-skill employment by $2 \%-4 \%$ and total restaurant employment by $1 \%-3 \%$.

\section{Introduction}

Until the early 1990s, the consensus was that an increase in the minimum wage causes a small but statistically and economically significant loss in employment (e.g., Brown, Gilroy, and Kohen 1982). While it was known that this need not be the case if firms have wage-setting power (Stigler 1946), the empirical results confirmed the qualitative predictions

We thank Gadi Barlevy, Jeff Campbell, John Kennan, Mike Kouparitsas, Lynn Riggs, Dan Sullivan, Ted To, and Marcello Veracierto for useful comments and Kate Godwin and Tina Lam for outstanding research assistance. We especially thank Charlie Brown for insightful comments that significantly improved the article. Contact Daniel Aaronson at daaronson@frbchi.org and Eric French at efrench@frbchi.org.

[Journal of Labor Economics, 2007, vol. 25, no. 1]

(C) 2007 by The University of Chicago. All rights reserved. 0734-306X/2007/2501-0006\$10.00 
of standard models of perfect competition, which most researchers suspected were relevant for industries that primarily employed minimum wage workers.

However, Card and Krueger's work in the early 1990s spawned a contentious debate over the magnitude, and perhaps even the sign, of the employment response. In a series of papers, they found no-or, in some cases, a small positive-employment response to an increase in the minimum wage. ${ }^{1}$ Moreover, they discuss a number of other facts that may be inconsistent with competitive markets but consistent with monopsony power, including a spike in the distribution of wages at the minimum and the prevalence of posted vacancies. Recent theoretical developments have been able to generate monopsony-like employment responses after minimum wage increases by introducing labor market search with frictions (Burdett and Mortensen 1998), efficiency wages (Manning 1995; Rebitzer and Taylor 1995), or monopsonistic competition with free entry (Bhaskar and To 1999).

This work has not gone unchallenged, as exemplified by the discussions in Card and Krueger (2000) and Neumark and Wascher (2000). The latter authors, again in a series of papers (e.g., see Neumark and Wascher [1996] for a review), consistently find an effect more in line with the Brown et al. (1982) literature review; a 10\% increase in the minimum wage leads to roughly a $2 \%$ decrease in teen employment. ${ }^{2}$ Others, including Deere, Murphy, and Welch (1995), Kim and Taylor (1995), and Burkhauser, Couch, and Wittenburg (2000), find even larger negative effects, on the order of $2 \%-6 \%$. This confusion is particularly acute since the majority of these papers use the same sources of variation to identify the employment elasticity (albeit often from different time periods or geographic areas), either the cross-sectional or time-series comovement of teenage employment and the minimum wage.

While many of these papers claim to be testing the market structure of low-wage labor markets, none consider explicitly what the competitive and monopsonistic models they use imply. In this article, we make such a demonstration. Using data from the restaurant industry, we calibrate a model of employment determination to infer employment and price re-

${ }^{1}$ See Card and Krueger (1995) for a review. A sampling of other papers that corroborate these findings includes Wellington (1991), Machin and Manning (1996, 1997), and Dickens, Machin, and Manning (1999). See Neumark and Wascher (2003) for a long list of international studies, many of which find no employment response.

${ }_{2}^{2}$ These results are consistent with views reported in a survey of leading labor economists (Fuchs, Krueger, and Poterba 1998). However, a full quarter of respondents believe that there is no teenage disemployment effect from a $10 \%$ increase in the minimum wage, and another quarter judge the response to be $3 \%$ or higher. 
sponses to a change in the minimum wage implied by the two market structures.

We initially calculate the responses assuming that restaurants are price takers in both the factor and product markets. ${ }^{3}$ Several pieces of information are supplied to the model, including factor costs, the intensity of usage of low-wage workers, the elasticity of substitution between factors, the elasticity of labor supply, and the elasticity of product demand. The model predicts that a $10 \%$ increase in the minimum wage reduces lowskill restaurant industry employment by roughly $2.5 \%-4 \%$ and total restaurant employment by $1.5 \%-3 \%$ under perfect competition. A second implication of perfect competition is that higher labor costs are pushed onto consumers in the form of higher prices.

Next, we augment the model so employers potentially have monopsony power in the labor market. Under monopsony, employment potentially rises in response to an increase in the minimum wage. An implication is that when employment rises, output also rises, and thus output prices fall. Therefore, the competitive and monopsonistic models have different employment and output price predictions.

We use the model's output price implications to test for the potential importance of monopsony behavior in the labor market. This test relies on research (e.g., Aaronson 2001; Aaronson, French, and MacDonald 2005) that shows that most of the higher labor costs incurred by employers are pushed onto consumers in the form of higher prices, a finding that is in sharp contrast to the prediction of monopsony models. Consequently, we infer that few restaurants will increase employment in response to a minimum wage increase. Using the most plausible range of estimates of the model's key parameters, we find that the employment response to a $10 \%$ change in the minimum wage is likely between $2 \%$ and $4 \%$ for low-skill workers and between $1 \%$ and $3 \%$ for total restaurant employment. We argue that the estimates are well within the bounds set in the empirical literature. All of these predictions are robust to allowing for monopolistic competition in the product market.

It is important to emphasize that our estimates are for the restaurant industry only. Nevertheless, this industry is a major employer of lowwage labor and therefore a particularly relevant one to study. ${ }^{4}$ However,

\footnotetext{
${ }^{3}$ We assume that the minimum wage affects wages and the price of the output good but does not affect the prices of other factor inputs.

${ }^{4}$ Prominent examples of studies that concentrate on the restaurant industry include Katz and Krueger (1992), Card and Krueger (1995, 2000), and Neumark and Wascher (2000). According to the Current Population Survey's Outgoing Rotation Groups, eating and drinking places (SIC 641) is the largest employer of workers at or near the minimum wage, accounting for roughly a fifth of such employees in 1994 and 1995. The next-largest employer, retail grocery stores, employs less than $7 \%$ of minimum-wage or near-minimum-wage workers. More-
} 
as a result of different intensities of use of minimum-wage labor, substitution possibilities, market structure, or demand for their products, other industries might face different employment responses.

Section II describes the basic framework of our study. In that section, we introduce the competitive and monopsony models and show how to use price pass-through to infer the extent of monopsony power. Many of the results from the section are discussed further in a longer version of this article, Aaronson and French (2006). Section III and the appendix at the end of this article discuss the main parameters used to calibrate the model and the results. Finally, Section IV offers some concluding comments.

\section{The Model}

This section outlines the structure of the model and the assumptions used to identify the employment response to a minimum wage change. We begin with the perfect competition case and then introduce monopsony power, offering some intuition for the ambiguous impact the latter has on employment. Finally, we provide a framework for bounding the importance of monopsony power in the labor market, using primarily the output price response to minimum wage changes.

\section{A. Model Setup}

Throughout this article, we assume that a large number, ${ }^{5} N$, of firms with identical production technologies and identical products are perfectly competitive in the product market, sell their products at a price, $p$, and choose their inputs to maximize profits, $\pi$ :

$$
\pi(K, L, H, M)=p Q-r K-w_{L} L-w_{H} H-p_{M} M,
$$

where $Q=F(K, L, H, M)$ is a constant elasticity of substitution aggregator of low-skill labor, $L$, high-skill labor, $H$, capital, $K$, and materials, $M$, purchased at prices $r, w_{L},{ }^{6} w_{H}$, and $p_{M}$, respectively:

$$
Q=\left(\alpha_{K} K^{\rho}+\alpha_{L} L^{\rho}+\alpha_{H} H^{\rho}+\left(1-\alpha_{K}-\alpha_{L}-\alpha_{H}\right) M^{\rho}\right)^{1 / \rho},
$$

where $\sigma \equiv 1 /(1-\rho)$ is the partial elasticity of substitution between $K$,

over, the intensity of use of minimum-wage workers in the eating and drinking industry is among the highest of the industrial sectors.

${ }^{5}$ We do not allow for exit or entry, although we allow the size of businesses to change in response to wage changes.

${ }^{6} \mathrm{We}$ assume that the minimum wage covers all employers in the labor market. However, employees in restaurants with revenues of less than $\$ 500,000$ per year are not covered by federal minimum wage law. 
$L_{L}, L_{H}$, and $M$ in the production of $Q$. $^{7}$ The assumption of constant elasticities of substitution between all factors is roughly consistent with the empirical literature described in Hamermesh (1993). The market price is

$$
p=Z\left(\sum_{n=1}^{N} Q_{n}\right)^{-1 / n}
$$

where $\sum_{n=1}^{N} Q_{n}$ is market output and $\eta$ is the elasticity of demand for the output good. Although the case we consider here is competition in the product market, augmenting the model for monopolistic competition in the product market complicates the analysis but does not change the results. ${ }^{8}$

\section{B. Long-Run Price and Employment Responses of Competitive Firms}

Assume that all low-skill workers are paid the minimum wage but that high-skill workers are paid above it (Sec. II.E relaxes the assumption that all low-skill workers are paid the minimum wage). Also assume that the minimum wage only affects the wage of low-skill workers and that the supplies of all factors of production to the firm are perfectly elastic.

Assuming that all firms can adjust all factors, the price and employment responses to a minimum wage hike, derived in the appendix of Aaronson and French (2006), have simple analytical solutions. When firms are perfectly competitive (or monopolistically competitive, as in the appendix of Aaronson and French [2006]) and have a constant returns production function, economic profits must be zero both before and after the wage change. Consequently, all changes in labor costs are passed onto the consumer, that is,

$$
\frac{d \ln p}{d \ln w_{\min }}=s_{L},
$$

where $s_{L} \equiv w_{L} L /\left(w_{L} L+w_{H} H+r K+p_{M} M\right)$ is low-skill labor's share of total costs. ${ }^{9}$

Because prices are higher after the minimum wage hike, the quantity produced declines by $s_{L} \eta \%$ for every $1 \%$ increase in the minimum wage.

${ }^{7}$ The constant returns production function assumption implies that the size of each firm is indeterminate. However, assuming infinitesimally decreasing returns to scale and an infinitesimally small fixed cost of running the firm preserves all the results yet implicitly defines a firm's size. Therefore, we consider the firm size problem unimportant.

${ }^{8}$ So long as firms face constant elasticity of demand, all of the remaining equations in this article are unaffected. See the appendix in Aaronson and French (2006).

${ }^{9}$ Under perfect competition, with no profits, $s_{L}$ is also equal to low-skill labor's share of revenue, $s_{L}=w_{L} L / p Q$. 
The elasticity of demand for low-skill labor, $\lambda \equiv d \ln L / d \ln w_{\min }$, is

$$
\lambda=-\left(1-\left(\frac{d \ln p}{d \ln w_{\text {min }}}\right)\right) \sigma-\left(\frac{d \ln p}{d \ln w_{\text {min }}}\right) \eta .
$$

Here $\lambda$ is rising (in absolute value) in the elasticity of substitution between labor and the other factors of production (the "substitution effect") and the elasticity of demand for the output good (the "scale effect"). ${ }^{10}$ The substitution effect measures the change in factor ratios given a wage change, holding output fixed. The scale effect measures the change in output given a wage change, holding factor ratios fixed. Inserting equation (4) into equation (5) yields equation $\left(2.7 a^{\prime}\right)$ in Hamermesh (1993) and equation (11.6) in Card and Krueger (1995).

Nevertheless, there are several reasons why one might be wary of the long-run competitive employment response shown in equation (5). It is to two of these concerns that we turn next. In Section II.C, we discuss the short-run employment response when firms cannot adjust their capital stock in response to a minimum wage change. Section II.D introduces monopsony power in the labor market.

\section{Short-Run Price and Employment Responses of Competitive Firms}

In the short run, firms might not be able to adjust their capital stock in response to a minimum wage change, perhaps because of high adjustment costs or the irreversibility of these investments. ${ }^{11}$ In order to capture the concept of fixed capital, we assume that firms choose capital in order

${ }^{10}$ Although the empirical evidence suggests that all elasticities of substitution between factors of production are roughly similar in magnitude, one could argue that some substitution elasticities are close to zero whereas others (such as the elasticity of substitution between high-skill and low-skill labor) are large. However, note that both eqq. (4) and (5) can also be derived for the production function

$$
Q=\min \left\{\left(\left(1-\alpha_{L}\right) H^{\rho}+\alpha_{L} L^{\rho}\right)^{1 / \rho}, \alpha_{K} K, \alpha_{M} M\right\},
$$

where $s_{L}$ is redefined as $s_{L} \equiv w_{L} L /\left(w_{L} L+w_{H} H\right)$. Therefore, by properly adjusting $\rho$ and $s_{L}$, it is possible to get some measure of the robustness of our results to different substitution elasticities between factors.

${ }^{11}$ Empirical work on the disemployment effect of the minimum wage typically focuses on annual changes to employment, comparing levels before and after the new minimum wage. This short-run response likely abstracts from many adjustments to the capital-labor ratio that may arise over time in response to higher wage bills. For example, in the fast food industry over the past decade or so, cash registers have been modified so that the cashier need not know the price of a product, only its appearance. These machines also save time by directly transferring orders from the cash register to the cooks. It is these long-run responses that are likely of greater interest to policy makers. Baker, Benjamin, and Stanger (1999) illustrate the potentially distinct employment effects that arise at different time horizons. 
to maximize profits, keeping the wage of low-skill labor constant. But, after the wage changes, the firm can adjust all factors except capital. ${ }^{12}$

In the appendix of Aaronson and French (2006), we show that, if capital cannot adjust, the price response to a change in the minimum wage is

$$
\frac{d \ln p}{d \ln w_{\min }}=\frac{s_{L}}{s_{K}(\eta / \sigma)+\left(1-s_{K}\right)} .
$$

Inserting equation (6) into equation (5) gives the short-run employment response.

An interesting special case arises when $\sigma$, the partial elasticity of substitution between factor inputs, and $\eta$, the elasticity of demand for the output good, are equal. In this situation, the price response is identical whether capital is fixed (eq. [6]) or flexible (eq. [4]). Additional labor costs are always and fully pushed onto consumers in the form of higher prices. To see why, note that the elasticity of capital in response to changes in the minimum wage when capital can adjust is

$$
\frac{d \ln K}{d \ln w_{\min }}=s_{L}(\sigma-\eta) .
$$

Therefore, if $\sigma=\eta$, we should expect no capital response to changes in the minimum wage, even if capital can adjust. Thus the fixity of capital is irrelevant.

A second interesting case is when the production function is Leontief (i.e., $\sigma=0$ ). So long as the firm can cover its variable costs (i.e., $p Q>$ $w_{L} L+w_{H} H+p_{K} K$ ), firms cannot increase profits by reducing output. Therefore, prices and employment are unaffected by changes in the minimum wage. One notable application is putty-clay models (Johansen 1959; Gilchrist and Williams 2000). Although most empirical studies find evidence of positive substitutability between factors of production (Hamermesh 1993), putty-clay models develop the idea that there may be substitutability between factors for firms being put into place but no substitutability for firms already in place. Therefore, substitutability between factors only exists in the long run as new firms enter the marketplace. In the short run, putty-clay models also predict no employment or price response to minimum wage hikes. Regardless, the key intuition, formalized in equation (5), is that price and employment responses are linked.

${ }^{12}$ This approach can be justified by the following three-period model. In period 1 , firms choose $K$ and believe that they know period 2 prices with probability 1 . In period 2, all prices are revealed, and the wage potentially changes. The firm can then pick $L$ and $M$. Although $K$ is set for period 2, the firm can pick period 3 values of $K$. In period 3, all prices were as anticipated. In this case, period 2 represents the short-run equilibrium, and period 3 represents the long-run equilibrium. 
Finally, part of the reduction in low-skill labor is potentially offset by increases in high-skill labor. The employment response of high-skill labor is

$$
\frac{d \ln H}{d \ln w_{\min }}=\left(\frac{d \ln p}{d \ln w_{\min }}\right)(\sigma-\eta)
$$

The first term shows the change in product price (which is also equal to the change in marginal cost). The second term has offsetting substitution and scale effects. After the minimum wage increases, high-skill labor becomes relatively cheaper than low-skill labor, causing firms to substitute to the former. However, the level of output falls, causing the firm to reduce all factors. If $\sigma=\eta$, this offset is exact and we should expect no high-skill labor response to changes in the minimum wage.

\section{The Short-Run Employment and Price Responses of Monopsonistic Firms}

Next, we derive the employment and price effects of minimum wage changes when firms are monopsonists in the labor market, or more specifically, monopsonistically competitive, as in Dickens et al. (1999) or Manning (2003). The contribution of this model relative to others is that we endogenize prices. The production function and product market are the same as in the previous section. We show that employment may rise in response to a minimum wage hike but that this implies that prices will fall.

Many researchers have argued that fast food restaurants are highly competitive and that therefore monopsony power is likely to be negligible. ${ }^{13}$ However, models such as Burdett and Mortensen (1998) where employee search is costly often imply that employers have some degree of monopsony power. Furthermore, Card and Krueger (1995) document several empirical facts that may be inconsistent with competitive models but that are consistent with monopsony models. For example, they argue that a well-documented spike in the wage distribution at the minimum implies that, unless there is a similarly sized and placed spike in the distribution of ability, some workers are not paid their marginal revenue product of labor. We show below that the presence of a spike in the minimum wages is not necessarily evidence of monopsony power. But other facts, such as the existence of posted vacancies, are not consistent with competition if it is costly to post a vacancy. Competitive theory implies that an employer can obtain an unlimited number of workers at

${ }^{13}$ Although Stigler (1946) was the first to observe the potential importance of monopsony power when analyzing minimum wage policy, he was clearly suspicious that this was a relevant scenario. 
the going wage rate and that any vacancy is immediately filled. Therefore, it seems plausible that restaurants have some amount of market power.

In this model, all low-skill workers are identical in their productivity, but because of differences in local labor market conditions, all firms in some markets pay above the minimum wage and all firms in other markets pay the minimum wage. ${ }^{14}$ Each of the $N$ firms within a given local labor market face the labor supply curve for low-skill labor, ${ }^{15}$

$$
L_{n}=\theta^{-\gamma_{1}} w_{L, n}^{\gamma_{1}} w_{L,-n}^{\gamma_{2}-\gamma_{1}},
$$

where $w_{L, n}$ is the wage offered by the $n$th firm and $w_{L,-n}$ is the average wage offered by all other firms in the market. Therefore, all $N$ firms compete in the same product and labor market. ${ }^{16}$ We assume that $\gamma_{1} \geq$ $\gamma_{2}$, so that the quantity of labor supplied to the firm is increasing in the wage offered by the firm and weakly falling in the wage offered by other firms in the market. We also assume that $\gamma_{2} \geq 0$ : if all firms in the market increase their wage, the total quantity of labor supplied in the market will increase. We assume that $\theta$ potentially varies by labor market, although we do not give $\theta$ a subscript for notational convenience. Therefore, within each local labor market, all firms face the same wage and output price, but the (low-skill) wage and output price varies across labor markets. is

Using equation (9), the inverse labor supply curve for low-skill labor

$$
w\left(L_{n}\right)=\theta L_{n}^{1 / \gamma_{1}} w_{L,-n}^{1-\left(\gamma_{2} / \gamma_{1}\right)},
$$

and their offered wage is

$$
w_{L}=\max \left\{w(L), w_{\min }\right\} .
$$

Note that in equilibrium all firms within a given market will purchase the same amount of factor inputs and will have the same level of output. Therefore, we drop the $n$ subscripts for notational convenience.

Figure 1 shows the competitive and monopsony solutions to the firm's problem. The competitive solution (if the firm is a price taker in the labor market with an exogenous wage $\left.w^{* *}\right)$ is for the firm to hire $L^{* *}$ workers at a wage $w^{* *}$. However, if the firm has monopsony power, the firm will pay only $w^{*}$ and will hire $L^{*}$ workers.

\footnotetext{
${ }^{14}$ We assume that the wage ratio between high-skill and low-skill workers is constant across labor markets. See Sec. II.F for more details.

${ }^{15}$ Manning (2003) derives an identical specification starting from a specification analogous to Dixit and Stiglitz (1977).

${ }^{16}$ Thus we allow for differences in wages and the importance of monopsony power across labor markets, although we assume that all employers of low-skill labor are identical within a labor market. This is an extreme assumption given that only $25 \%$ of all minimum-wage workers are employed in the restaurant industry and thus restaurants compete with many types of firms in the labor market.
} 


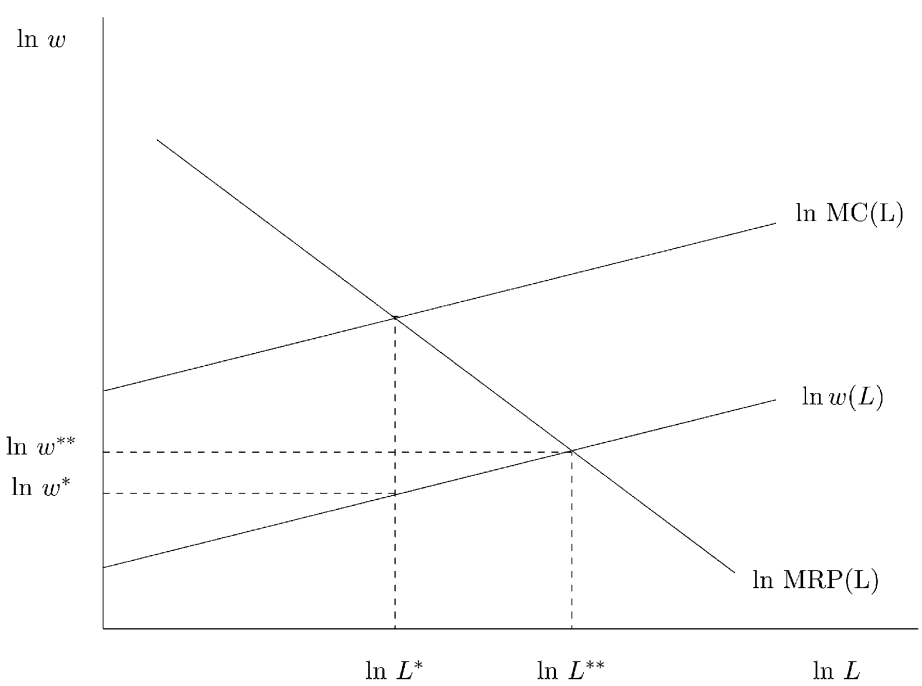

FIG. 1.-Illustration of monopsony equilibrium

Whether employment rises, falls, or remains constant in response to an increase in the minimum wage is determined by the level of the minimum wage. The simplest case occurs when the minimum wage is not binding $\left(w_{\min }<w^{*}\right)$. In this case, a small change in the minimum wage has no effect on employment. Equilibrium employment and wages are $L^{*}$ and $w^{*}$, respectively.

Now, suppose that the minimum wage is set between $w^{*}$ and $w^{* *}$. In this case, employment in a labor market with a minimum wage (e.g., $L_{\min }$ in fig. 2) is greater than employment in the absence of the minimum wage $\left(L^{* *}\right) .^{17}$ The intuition for this result is that, although the minimum wage increases the average cost of labor for the firm, it reduces the marginal cost of labor from $\left(1+\left(1 / \gamma_{1}\right)\right) w^{*}$ to $w_{\min }$. Below $L_{\min }$, the marginal cost of labor, is the minimum wage. Whether the firm hires $L_{\min }$ or $L_{\min }-1$ workers, all workers are paid $w_{\min }$. However, for employment levels above $L_{\min }$, the marginal cost of labor is above the minimum wage;

${ }^{17}$ Note that a change in the minimum wage changes both the labor supply curve faced by the firm (because $w_{L,-n}$ changes) and the MRP(L) curve faced by the firm (because the output price charged by other firms changes). Thus the figures are not helpful for understanding the quantitative price and employment responses, although they are helpful for understanding the qualitative responses. Furthermore, because the labor supply curve and MRP(L) curve shift in response to the minimum wage, changing the minimum wage also changes the boundary conditions $w^{*}$ and $w^{* *}$. Below, when we refer to $w^{*}$, we mean the value of it for which $w^{*}=w_{\min }$, and $w^{* * *}$ is the value for which $w^{* *}=w_{\min }$. Therefore, fig. 2 is not technically correct, although it helps clarify the intuition of the model. 


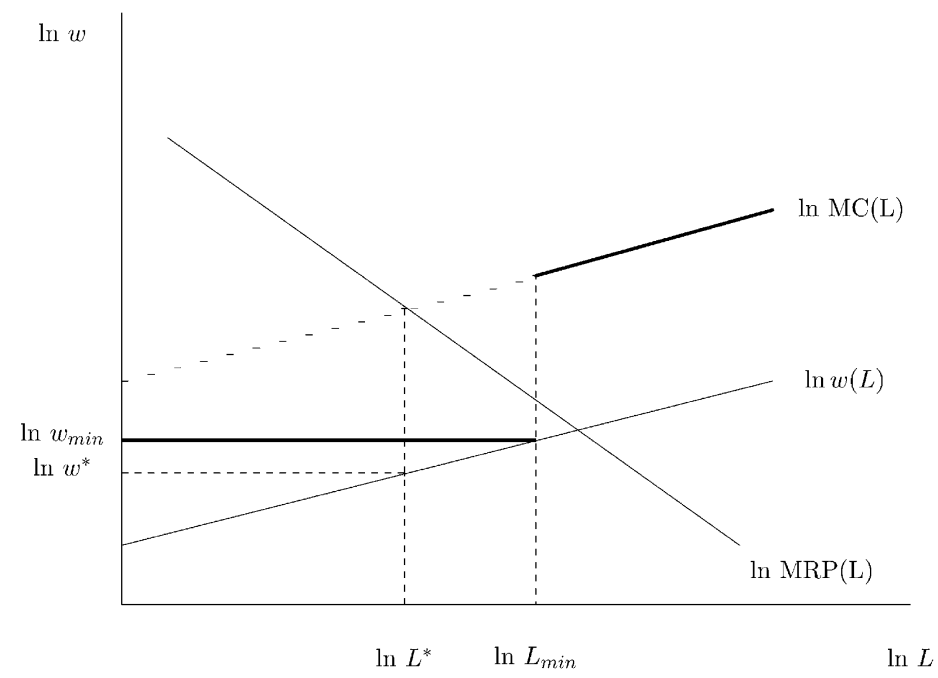

FIG. 2.-Illustration of monopsony equilibrium with minimum wage (bold line denotes $\ln \mathrm{MC}(\mathrm{L})$ curve).

no additional workers will work for $w_{\min }$. The employer must increase the pay of all workers in order to obtain an additional one. Consequently, employment is determined by the intersection of the minimum wage and the inverse labor supply function $w(L)$. Therefore, increases in the minimum wage lead to increases in employment for $w_{\min } \in\left[w^{*}, w^{* *}\right)$. Specifically, the percent change in employment in the market (and thus the percent change in employment for every firm in the market) is

$$
\left.\frac{d \ln L}{d \ln w_{\min }}\right|_{w_{L, n}=w_{L,-n}=w_{\min }}=\gamma_{2} .
$$

The important insight is that, although $\gamma_{1}$ is the relevant parameter for understanding the gap between the wage and the marginal revenue product of labor, ${ }^{18}$ it is $\gamma_{2}$ that is important for understanding the employment response to the minimum wage.

We now solve out for the price response under monopsony when $w_{\min } \in\left[w^{*}, w^{* *}\right)$. In the appendix to Aaronson and French (2006), we show that given equation (12) but allowing for prices and other factors

${ }^{18}$ In the absence of a minimum wage, the marginal revenue product of labor is $\left(1+\left(1 / \gamma_{1}\right)\right)$ times the wage, and for this reason $1 / \gamma_{1}$ is sometimes known as the rate of exploitation. 
of production to adjust in the same way we did when allowing for a competitive labor market yields

$$
\begin{gathered}
\left.\frac{d \ln p}{d \ln w_{\min }}\right|_{w_{L, n}=w_{L,-n}=w_{\min }}= \\
\qquad \begin{array}{ll}
-\left[s_{L} \gamma_{2}(1+(1 / \gamma(\theta))] /\left(\sigma\left(1-s_{L}\right)+s_{L} \eta\right)\right. & \text { if capital can adjust, } \\
-\left[s_{L} \gamma_{2}(1+(1 / \gamma(\theta))] /\left(\sigma\left(1-s_{L}-s_{K}\right)+\left(s_{L}+s_{K}\right) \eta\right)\right. & \text { if capital cannot adjust }
\end{array}
\end{gathered}
$$

for some $1 / \gamma(\theta) \in\left[0,\left(1 / \gamma_{1}\right)\right]$, where

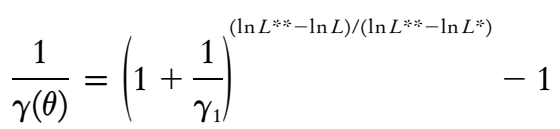

measures the difference between the wage and the marginal revenue product of labor, the vertical distance between $\ln w(L)$ and $\ln \mathrm{MRP}(\mathrm{L})$ in figure 1.

Finally, if the minimum wage lies above the point of intersection of the inverse labor supply function and the marginal revenue product of labor function $\operatorname{MRP}(\mathrm{L})$, that is, $w_{\min }>w\left(L^{* *}\right)$, employment falls as the minimum wage rises. The marginal cost of labor function, $\mathrm{MC}(\mathrm{L})$, is always equal to the minimum wage. The firm then sets employment by equating the $\mathrm{MRP}(\mathrm{L})$ curve and the minimum wage, as in Sections II.B and II.C. Because the $\operatorname{MRP}(\mathrm{L})$ curve slopes down, increases in the minimum wage unambiguously lead to a reduction in employment. The magnitude of the disemployment effect was discussed in Section II.B for the case where capital can adjust and in II.C for the case where capital cannot adjust.

Note that the price response in equation (13) is unambiguously negative. Also recall that equations (4) and (6) showed that, under competition (or if $\left.w_{\min }>w^{* *}\right)$, wage hikes unambiguously increase prices. Therefore, in response to a minimum wage hike, employment and price changes are always negatively related. ${ }^{19}$ Employment falls and prices rise under perfect competition, and employment can rise and prices can fall under monopsony. Consequently, price data offer an alternative means of inferring the importance of monopsony power in the labor market.

E. Using Price Pass-Through to Infer the Extent of Monopsony Power

This section proposes a method to infer the extent to which monopsonistic behavior is important, using empirical estimates of price passthrough, $E\left[d \ln p / d \ln w_{\min }\right]$. Furthermore, we show that once we infer the

${ }^{19}$ Again, the substitutability of high-skill labor and low-skill labor can result in an offsetting employment response of high-skill labor. 
importance of monopsony behavior, we can infer the employment response to increasing the minimum wage.

We allow for the fact that the minimum wage binds in some labor markets but not in others because of variation in labor supply (i.e., $\theta$ ). Given the results above, and assuming that capital cannot adjust, the price response to a minimum wage change is

$$
\begin{array}{ll}
\frac{d \ln p}{d \ln w_{\min }}(\theta) & = \\
\begin{cases}s_{L} /\left[s_{K}(\eta / \sigma)+\left(1-s_{K}\right)\right] & \text { if } w_{\min } \geq w^{* * *}, \\
-\left[s _ { L } \gamma _ { 2 } \left(1+(1 / \gamma(\theta)] /\left(\sigma\left(1-s_{L}-s_{K}\right)+\left(s_{L}+s_{K}\right) \eta\right)\right.\right. & \text { if } w^{*} \leq w_{\min }<w^{* * *}, \\
0 & \text { if } w_{\min }<w^{*} .\end{cases}
\end{array}
$$

Line 1 is derived in equation (6) and line 2 in equation (13). If the minimum wage does not bind (line 3 ), output prices will not respond to a minimum wage increase.

The employment response is

$$
\lambda(\theta)= \begin{cases}-\sigma-(\eta-\sigma)\left(s_{L} /\left[s_{K}(\eta / \sigma)+\left(1-s_{K}\right)\right]\right) & \text { if } w_{\min } \geq w^{* * *}, \\ \gamma_{2} & \text { if } w\left(L^{* *}\right) \leq w_{\min }<w^{* * *}, \\ 0 & \text { if } w_{\min }<w^{*} .\end{cases}
$$

Line 1 is derived using equation (5), plus the price response in line 1 of equation (14). Line 2 is derived in equation (12). If the minimum wage is not binding, as in line 3 , there is no employment response.

Define $\operatorname{Pr}\left(w_{\min }>w^{*}\right)$ as the share of firms that pay the minimum wage and $V=\operatorname{Pr}\left(w_{\min } \geq w^{* * *} \mid w_{\min }>w^{*}\right)$ as the share of firms facing a binding minimum wage such that the minimum wage is equal to the $\operatorname{MRP}(L)$. If $V=1$, then all firms affected by the minimum wage behave competitively in the labor market. If $V=0$, then all firms affected behave as monopsonists. If we knew $V$, we could use equation (15) to compute the average employment response. If all firms have the same elasticities and factor shares, then

$$
\begin{aligned}
\mathrm{E}[\lambda]=\int_{\theta} & \lambda(\theta) \mathrm{dF}(\theta)=-\operatorname{Pr}\left(w_{\min }>w^{*}\right) \\
& \times\left(V\left(\sigma+(\eta-\sigma)\left[s_{L} /\left[s_{K}(\eta / \sigma)+\left(1-s_{K}\right)\right]\right]\right)-(1-V)\left(\gamma_{2}\right)\right) .
\end{aligned}
$$


Fortunately, we can calculate $V$ by using the extent of price passthrough. Analogous to equation (16), the average price response is

$$
\begin{aligned}
E\left[\frac{d \ln p}{d \ln w_{\min }}\right] & =\int_{\theta} \frac{d \ln p}{d \ln w_{\min }}(\theta) d F(\theta) \\
& =\operatorname{Pr}\left(w_{\min }>w^{*}\right) s_{L} \times\left(\left[\frac{V}{s_{K}(\eta / \sigma)+\left(1-s_{K}\right)}\right]-\left[\frac{(1-V) \gamma_{2}(1+(1 / \gamma(\theta)))}{\left(\sigma\left(1-s_{L}-s_{K}\right)+\left(s_{L}+s_{K}\right) \eta\right)}\right)\right] .
\end{aligned}
$$

Rearranging equation (17), we can solve explicitly for $V$ :

$$
\begin{aligned}
& V= \\
& \frac{E\left[d \ln p / d \ln w_{\min }\right]\left[1 / \operatorname{Pr}\left(w_{\min }>w^{*}\right)\right]+s_{L} \gamma_{2}[1+(1 / \gamma(\theta))] /\left(\sigma\left(1-s_{L}-s_{K}\right)+\left(s_{L}+s_{K}\right) \eta\right)}{\left[s_{L} /\left(s_{K}(\eta / \sigma)+\left(1-s_{K}\right)\right)\right]+\left[s_{L} \gamma_{2}(1+(1 / \gamma(\theta)))\right] /\left(\sigma\left(1-s_{L}-s_{K}\right)+\left(s_{L}+s_{K}\right) \eta\right)} .
\end{aligned}
$$

Values of $E[d \ln p / d \ln w], s_{K}, \gamma_{1}, \gamma_{2}, \eta$, and $\sigma$ can be computed or taken from the existing literature. We report the values that we use in table 1 and in the appendix. However, we do not have direct estimates of $\operatorname{Pr}\left(w_{\min }>w^{*}\right)$ or $s_{L}$. In Section II.F, we show how to infer these objects using additional information.

In deriving equations (17) and (18), we assumed that $s_{L}$ and $s_{K}$ do not vary across labor markets. However, the theory presented above indicates that the factor mix (and thus $s_{L}$ and $s_{K}$ ) varies across labor markets. In the appendix, we provide empirical evidence, based on the 1997 Economic Census for Accommodations and Food Services and the outgoing rotation files of the Current Population Survey (CPS), that there is little geographic variation in labor's share. In the appendix to Aaronson and French (2006), we also show that, given the calibrated values described in the appendix, geographic differences in low-skill labor's share are likely small, varying by less than $15 \%$ (or 4 percentage points) across labor markets. ${ }^{20}$

We make two final observations about the model. First, all of the competitive and monopsony predictions described in this section are robust to allowing for monopolistic competition in the product market so long as there is a constant elasticity of demand. This result is established in the appendix of Aaronson and French (2006).

Second, this model generates a spike in the distribution of wages at the

${ }^{20}$ Given the parameters listed in Sec. III, allowing for labor's share to vary across markets had only a modest effect on our results. 
minimum, even if monopsony power is nonexistent. ${ }^{21}$ This is the case so long as $\sigma$ and $\eta$ are finite (i.e., labor is not a perfect substitute for materials or capital, and there is finite elasticity of demand for the output good). Under these reasonable assumptions, low-skill labor will still be used as a factor of production even when the price of labor rises, and increases in output prices will lead to a reduction, but not to a cessation, in output. In a geographically segmented labor market with heterogeneous but not perfectly substitutable labor, raising the minimum wage slightly above the competitive wage will not shut down the industry. Even if labor were homogenous, increasing the minimum wage would not shut down an industry. Therefore, higher labor costs caused by an increase in the minimum wage can be (partially) pushed onto consumers.

\section{F. Aggregation Issues}

Ideally, we would like to use parameters to calibrate the model that correspond to restaurants that pay at or near the minimum wage. Unfortunately, we often must rely on estimates in the literature that come from more aggregated sources, particularly the entire restaurant industry. If all restaurants were identical, facing identical labor and product markets, using aggregate data would not be a problem. But clearly this is not the case.

Perhaps the most serious concern is that we do not know either the fraction of restaurants that pay the minimum wage (i.e., $\operatorname{Pr}\left(w_{\min }>w^{*}\right)$ ) or low-wage labor's share at restaurants that pay the minimum wage, $s_{L}$. However, we do have a good amount of related information, including the share of restaurant workers who are paid the minimum wage $\left(\operatorname{Pr}\left(w_{\min }=w_{i}\right)\right)$, labor's share of total costs in the restaurant industry $\left(s_{L}+s_{H}\right)$, the fraction of workers who are low skill $(\operatorname{Pr}(L))$ at any given restaurant (and are thus paid the minimum wage in low-wage markets), the average number of workers per restaurant by high-wage $\left(Z_{-\min }\right)$ and low-wage $\left(Z_{\min }\right)$ establishments, and minimum-wage labor's share of the aggregate wage bill.

In order to recover $\operatorname{Pr}\left(w_{\min }>w^{*}\right)$ and $s_{L}$, we assume that there are only three types of labor markets (i.e., $\theta$ can take on only three different values): those that pay the minimum wage to workers and behave competitively (i.e., markets where the minimum wage intersects the $\mathrm{MRP}(\mathrm{L})$ curve for

${ }^{21}$ Within our model, all low-skill workers are paid the same wage, although there is wage dispersion across labor markets. If two workers within the same labor market had different wages before the minimum wage hike, they will have different wages after the minimum wage hike. There is some empirical evidence against this implication of the model. Card and Krueger (1995) show that, within states, minimum wage hikes significantly compress wages for those paid near the minimum wage. Unless labor markets are smaller than states (which may be true for minimumwage workers), this is evidence against the model. 
every firm in the market), markets that behave monopsonistically (i.e., markets where the minimum wage intersects the labor supply curve for every firm in the market), and markets where the minimum wage does not bind. In markets where the minimum does not bind, all firms pay their low-skill workers wagediff $\times w_{\min }$. Furthermore, high-wage workers are paid a constant multiple of the wage of low-skill workers within the market. Thus, there is a four-point wage distribution, with heterogeneity in two dimensions: high-skill and low-skill workers and high-wage and low-wage labor markets. We assume that $\operatorname{Pr}(L)$ is the same in high-wage and low-wage labor markets. ${ }^{22}$

In the appendix to Aaronson and French (2006), we show that

$$
\begin{aligned}
\operatorname{Pr}\left(w_{\min } \geq w\left(L^{*}\right)\right) & = \\
& \frac{\left[\operatorname{Pr}\left(w_{\min }=w_{i}\right) / \operatorname{Pr}(L)\right]}{1-\left[\operatorname{Pr}\left(w_{\min }=w_{i}\right) / \operatorname{Pr}(L)\right]+\left[\left(\operatorname{Pr}\left(w_{\min }=w_{i}\right) / \operatorname{Pr}(L)\right] /\left(Z_{-\min } / Z_{\min }\right)\right.},
\end{aligned}
$$

where the right-hand side of equation (19) collapses to $\operatorname{Pr}\left(w_{\min }=w_{i}\right) /$ $\operatorname{Pr}(L)$ when $Z_{-\min } / Z_{\min }=1$. Using household data, we can measure $\operatorname{Pr}\left(w_{\min }=w_{i}\right)$ fairly accurately.

Because we have information on $s_{L}+s_{H}$ but not for $s_{L}$ alone, we must infer the relative shares of each factor. In order to infer $s_{L}$, we match minimum-wage labor's share of the total wage bill (i.e., the share of total wages going to minimum-wage labor) to the data. In the appendix to Aaronson and French (2006), we show that low-skill labor's share is

$$
\begin{aligned}
s_{L}= & \left(s_{L}+s_{H}\right) \times(\text { minimum-wage labor's share of the total wage bill }) \\
& \times\left(\frac{\operatorname{Pr}\left(w_{\min } \geq w\left(L^{*}\right)\right)+\left(1-\operatorname{Pr}\left(w_{\min } \geq w\left(L^{*}\right)\right)\right) \times \text { wagediff } \times\left(Z_{-\min } / Z_{\min }\right)}{\operatorname{Pr}\left(w_{\min } \geq w\left(L^{*}\right)\right)}\right) .
\end{aligned}
$$

The right-hand side of equation (20) has three parts. The first part is labor's share. The product of the second and third parts are the share of labor costs going to low-skill labor.

${ }^{22}$ Assuming that wages for high-skill workers is a constant multiple of the wages of low-skill workers and that the fraction of low-skill workers does not vary across labor markets is fairly consistent with the data. The coefficient of variation of restaurant worker wages within a city varies very little with the average wage within a city, according to our calculations using CPS data. This is consistent with our joint hypothesis. 


\section{G. Total Employment Effects}

Finally, we are not only interested in low-skill employment but total employment as well. To calculate the impact on total restaurant industry employment, denoted $E$, we must compute a weighted average of the lowand high-skill workers' employment responses:

$$
\frac{d \ln E}{d \ln w_{\min }}=\left(\frac{d \ln L}{d \ln w_{\min }}(\operatorname{Pr}(L))+\frac{d \ln H}{d \ln w_{\min }}(1-\operatorname{Pr}(L))\right) \times \operatorname{Pr}(\text { lowwage }),
$$

where $\operatorname{Pr}$ (lowwage) is the share of workers who work for a minimumwage restaurant,

$$
\begin{aligned}
\operatorname{Pr}(\text { lowwage }) & = \\
& \frac{\operatorname{Pr}\left(w_{\min } \geq w\left(L^{*}\right)\right)}{\operatorname{Pr}\left(w_{\min } \geq w\left(L^{*}\right)\right)+\left(1-\operatorname{Pr}\left(w_{\min } \geq w\left(L^{*}\right)\right)\right)\left(Z_{-\min } / Z_{\min }\right)},
\end{aligned}
$$

and is derived in equation (95) of Aaronson and French (2006).

\section{Results}

\section{A. Parameters}

Table 1 provides a summary of the parameters that we use to calibrate the model. The right-hand column gives the baseline values that we use, along with the range of values considered in the robustness checks to follow. The appendix provides a full accounting of how we chose these values.

\section{B. Employment and Price Responses}

Table 2 reports our estimates of the employment response to a $1 \%$ minimum-wage hike under various scenarios for the key parameters. In the top panel, the employment responses are based on a price response $\left(E\left[d \ln p / d \ln w_{\min }\right]=0.07\right)$ that is consistent with the aggregate results in Aaronson (2001) and Aaronson et al. (2005). The bottom panel is based on a price response that is 1.5 standard errors below this estimate $\left(E\left[d \ln p / d \ln w_{\min }\right]=0.05\right) .{ }^{23}$ Within each panel, the demand elasticity, $\eta$, varies between 0.5 and 1.0 , and the elasticity of substitution, $\sigma$, between 0.5 and 0.8. The remaining parameters are set to our best assessment of their value, as described in table 1 and the appendix. All reported employment responses are short run. ${ }^{24}$

${ }^{23}$ These lower estimates are consistent with some specifications reported in Aaronson (2001).

${ }^{24}$ Predicted short-run price responses depend on how much the ratio $\eta / \sigma$ varies from one. Given the range of estimates for $\eta$ and $\sigma$ that we consider likely, the difference between the long-run and short-run response is very small. 


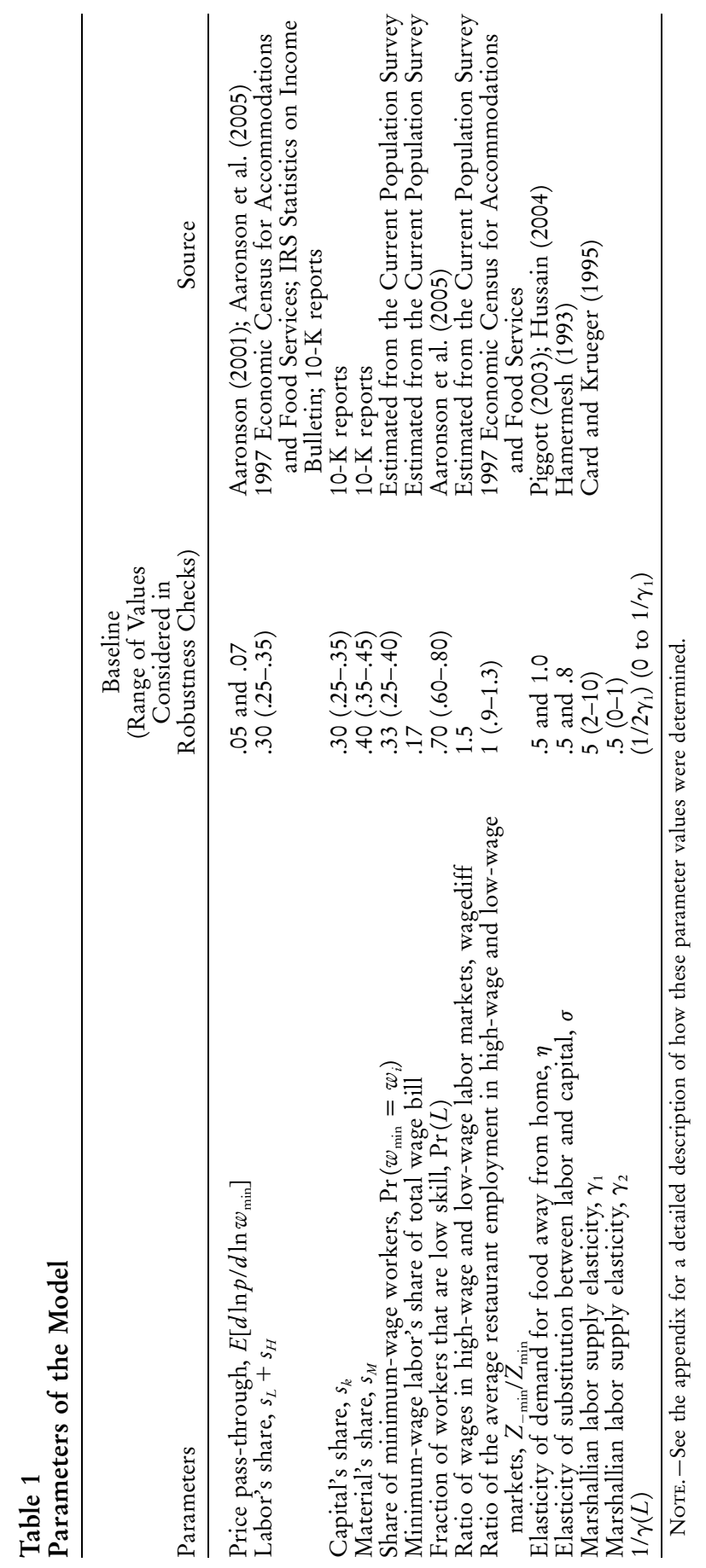

This content downloaded from 128.041.061.139 on August 11, 2016 07:28:07 AM

All use subject to University of Chicago Press Terms and Conditions (http://www.journals.uchicago.edu/t-and-c). 
Table 2

Estimates of $\lambda$ under Different Assumptions about Labor Market Structure, Price Responses, the Elasticity of Demand for Food Away from Home $(\eta)$, and the Elasticity of Substitution between Labor and Capital $(\sigma)$

\begin{tabular}{|c|c|c|c|c|c|}
\hline \multirow[b]{2}{*}{ Parameter Assumptions } & \multirow{2}{*}{$\begin{array}{l}\text { Competitive } \\
\text { Low-Skill } \\
\text { Employment } \\
\text { Response } \\
\text { (1) }\end{array}$} & \multirow{2}{*}{$\begin{array}{l}\text { Extent of } \\
\text { Monopsony } \\
\text { Power } \\
(V) \dagger \\
(2)\end{array}$} & \multicolumn{3}{|c|}{$\begin{array}{c}\text { Employment } \\
\text { Response } \\
\text { When Extent of } \\
\text { Monopsony Power } \\
\text { Is Included } \\
\end{array}$} \\
\hline & & & $\begin{array}{l}\text { Low } \\
\text { Skill } \\
\text { (3) }\end{array}$ & $\begin{array}{c}\text { High } \\
\text { Skill } \\
(4)\end{array}$ & $\begin{array}{c}\text { Total } \\
(5)\end{array}$ \\
\hline \multicolumn{6}{|l|}{ Price response, $E\left[d \ln p / d \ln w_{\min }\right]=.07$ : } \\
\hline$\eta=.5, \sigma=.8$ & -.36 & .98 & -.34 & .02 & -.23 \\
\hline$\eta=1.0, \sigma=.8$ & -.39 & 1.10 & -.45 & -.01 & -.32 \\
\hline$\eta=.5, \sigma=.5$ & -.23 & 1.04 & -.25 & .00 & -.18 \\
\hline$\eta=1.0, \sigma=.5$ & -.26 & 1.21 & -.36 & -.04 & -.26 \\
\hline \multicolumn{6}{|l|}{ Price response, $E\left[d \ln p / d \ln w_{\min }\right]=.05$ : } \\
\hline$\eta=.5, \sigma=.8$ & -.36 & .82 & -.25 & .02 & -.17 \\
\hline$\eta=1.0, \sigma=.8$ & -.39 & .90 & -.33 & -.01 & -.23 \\
\hline$\eta=.5, \sigma=.5$ & -.23 & .89 & -.19 & .00 & -.13 \\
\hline$\eta=1.0, \sigma=.5$ & -.26 & 1.00 & -.26 & -.03 & -.19 \\
\hline
\end{tabular}

The first column of table 2 displays the low-skill employment response to a $1 \%$ minimum wage increase under the assumption that all firms are price takers in the labor market, $\lambda_{\text {comp }} \times \operatorname{Pr}\left(w_{\min }>w^{*}\right)$. Employment responses are described in equations (5) and (6) for firms where the minimum wage binds. That is, labor markets are perfectly competitive, but some firms pay above the minimum wage. First, consider the case where $\eta=0.5$ and $\sigma=0.8$. Under these conditions, a $1 \%$ increase in the minimum wage cuts the low-skill food away from home workforce by $0.36 \%$. If $\eta=1.0$, the disemployment case is only slightly larger, approximately $0.39 \%$. The estimates are a bit more sensitive to $\sigma$. When $\sigma=0.5, \lambda_{\text {comp }} \times \operatorname{Pr}\left(w_{\min }>\right.$ $\left.w^{*}\right)$ falls to between 0.23 and 0.26 . Reducing the elasticity of substitution between factors eases the disemployment effect because firms have less opportunity to substitute from labor to other factors. Accordingly, if $\sigma$ is as high as one, the competitive employment response is over 0.5 . While the variety of values are noteworthy, given that the experiment covers what we consider to be the range of plausible values for $\eta$ and $\sigma$ (and other parameters), it appears to us that the employment response is not especially sensitive to reasonable parameter choices. Therefore, we can place reasonably tight bounds on the low-skill employment response under fairly strict assumptions about labor market structure.

Next, we introduce monopsony power in the labor market. Recall that 
increases in the minimum wage trace out the labor-supply curve (with elasticity $\gamma_{2}$ ) for monopsonists. Consequently, if all firms are monopsonists, minimum wage hikes significantly increase employment. ${ }^{25}$ Since firms are adding workers in response to a minimum wage change, output increases and prices fall. The model predicts that the price elasticity under monopsony is roughly -0.07 . By comparison, the price elasticity under competition tends to be around 0.07 .

Column 2 of table 2 reports the value of $V$, which is, as described in equation (18), identified by the degree of actual pass-through relative to the pure monopsony and perfect competition cases. A number substantially below one would imply that monopsony power is important. ${ }^{26}$ For example, if $\eta=0.5, \sigma=0.5$, and $E\left[d \ln p / d \ln w_{\min }\right]=0.07$, then $V=$ 1.04 , suggesting that there is little monopsony power in the industry. However, as factors become more substitutable, the elasticity of demand becomes less elastic, or price responses are muted, the implied amount of monopsony power increases. For example, if $\sigma=0.8, \eta=0.5$, and $E\left[d \ln p / d \ln w_{\min }\right]=0.05, V=0.82$.

Column 3 of table 2 reports our estimate of the low-skill employment response to a $1 \%$ minimum-wage change when the extent of monopsony power is accounted for explicitly. Calculations are based on equation (16). Like our estimates developed in the perfect competition setting, these employment responses tend to cluster, in this case in the -0.2 to -0.4 range, with the former appearing when $\sigma$ is low, $\eta$ is low, and/or price responses are high. A moderate reading of the parameters $(\sigma=0.65$, $\eta=0.75$, and $\left.E\left[d \ln p / d \ln w_{\min }\right]=0.06\right)$ produces a $V$ of 0.99 and a lowskill employment response of $-0.3 .^{27}$

Of course, these estimates ignore the impact on high-skill employment $\left(E\left[\Delta \ln H / \Delta \ln w_{\min }\right]\right)$ and therefore potentially give a misleading picture of the total employment effect $\left(E\left[\Delta \ln E / \Delta \ln w_{\min }\right]\right)$. Column 4 of table 2 shows that the employment response for high-skill workers is always negligible.

To estimate the impact on total restaurant industry employment, we

${ }^{25}$ For example, when $\gamma_{2}=0.5, \lambda_{\text {monop }} \times \operatorname{Pr}\left(w_{\min }>w^{*}\right)=0.24$

${ }^{26}$ The value of $V$ can exceed one if firms pass on more of a price increase than would be expected given perfect competition. Empirically, overshifting of ad valorem taxes has been found by, among others, Besley and Rosen (1999) in the retail apparel industry and Karp and Perloff (1989) in the Japanese television market.

${ }^{27}$ The only other parameters that have a substantive impact on these magnitudes are labor share $\left(s_{L}+s_{H}\right)$ and the share of workers that are low skill $(\operatorname{Pr}(L))$. To get an indication of the sensitivity of the results, we start with the baseline described above (where $\sigma=0.65, \eta=0.75$, and $E\left[d \ln p / d \ln w_{\min }\right]=0.06$ ). Altering $s_{L}+s_{H}$ between 0.25 and 0.35 stretches the low-skill employment response to be between -0.36 and -0.27 . If, instead, we allow $\operatorname{Pr}(L)$ to be between 0.6 and 0.8 , the low-skill employment response falls in the range of -0.37 to -0.26 . 
must compute a weighted average of the low- and high-skill workers' employment responses, as in equation (21). These results are presented in column 5. The total employment response to a $1 \%$ increase in the minimum wage is roughly -0.2 , with estimates ranging between -0.1 to -0.3 under reasonable parameter choices. ${ }^{28}$

Not only do we compare our predicted aggregate price increases to estimates in the literature, but we also compare predictions of price increases in areas where the minimum wage does not bind with areas where the minimum wage does bind. Consider the regression

$$
\left(\frac{\Delta \ln p}{\Delta \ln w_{\min }}\right)_{i}=\gamma \operatorname{Pr}\left(w_{i}=w_{\min }\right)+\text { error }_{i},
$$

where $\left(\Delta \ln p / \Delta \ln w_{\min }\right)_{i}$ is the average city-level price response and $\operatorname{Pr}\left(w_{i}=w_{\min }\right)$ is the probability that an individual in city $i$ is paid the minimum wage before the minimum wage hike. Assuming that all labor markets are competitive implies that the regression coefficient $\gamma$ should be from 0.15 to 0.22 , depending on the specification..$^{29}$ Furthermore, allowing for the inferred amount of monopsony from table 2 , the regression coefficient $\gamma$ should be between 0.15 and $0.21 .^{30}$

Using a panel of city level data, Aaronson et al. (2005) find that this regression has a coefficient of 0.36 with a standard error of 0.24 . Therefore, estimated pass-through is greater than, but not statistically different from, the predicted competitive response or the implied responses that allow for some monopsony power as in table 2 .

\section{The Importance of Aggregation}

How does accounting for heterogeneity affect our results? Table 3 shows estimates of the competitive and monopsony price responses, $V$, and the competitive, monopsony, and expected total employment responses to a $1 \%$ change in the minimum wage under three scenarios. Model 1 allows for labor market heterogeneity but not worker-type heterogeneity, model 2 for worker-type heterogeneity but not labor mar-

\footnotetext{
${ }^{28}$ Furthermore, the other parameters, as discussed in the previous footnote, have a negligible impact (always less than 0.03 ) on the total employment response.

${ }^{29}$ Predicted values are obtained by setting $V=1$ in eq. (17), using the value of $s_{L}$ in eq. (20), and the formula for the relationship between $\operatorname{Pr}\left(w_{\min }=w_{i}\right)$ and $\operatorname{Pr}\left(w_{\min } \geq w\left(L^{*}\right)\right)$ derived in eq. (19). The range of values for $\gamma$ is obtained by varying the parameters in the same way as was done in table 2.

${ }^{30}$ To make this calculation, we assume that there are multiple labor markets within each city. The minimum wage binds in some markets but not in others. In all cities there is a probability $V$ that firms in the market have monopsony power if the minimum wage binds in that market. We then use the inferred value of $V$ from the model and use eqq. (17), (20), and (19).
} 
Table 3

Estimates of Price and Total Employment Responses under Different Assumptions about Aggregation

\begin{tabular}{lccc}
\hline Estimates & Model 1 & Model 2 & Model 3 \\
\hline $\begin{array}{l}\text { Price response }\left(E\left[d \ln p / d \ln w_{\min }\right]\right) \\
\text { under perfect } c \text { ompetition }\end{array}$ & .099 & & \\
Price response $\left(E\left[d \ln p / d \ln w_{\min }\right]\right)$ & & .051 & .064 \\
$\quad$ under monopsony & -.109 & -.056 & -.071 \\
The extent of monopsony power $(V)$ & .86 & 1.18 & 1.04 \\
Total employment response: & -.17 & -.17 & -.17 \\
$\quad$ Under perfect competition & .17 & .17 & .17 \\
$\quad \begin{array}{l}\text { Under monopsony } \\
\text { Weighted by } V\end{array}$ & -.12 & -.22 & -.18 \\
Heterogeneity in skill type & No & Yes & Yes \\
Heterogeneity in labor market type & Yes & No & Yes \\
\hline
\end{tabular}

Note. - See text for detail. We use $\eta=.5, \sigma=.5, E\left[d \ln p / d \ln w_{\min }\right]=.07$ and the parameter values from table 2. Wagediff is set to 1.5 for models 2 and 3 and to match minimum-wage labor's share of the total wage bill and $\operatorname{Pr}\left(w_{\min }=w_{i}\right)$ in model 1 .

ket-type heterogeneity, and model 3 for heterogeneity in both labor market and worker types. Specifically, model 1 assumes that some stores pay all of their workers the minimum wage and the remainder pay none of their workers the minimum wage. There is only one type of labor, but variation in labor supply (i.e., $\theta$ ) causes the minimum wage to bind in some markets and not others. Model 2 assumes that all restaurants within a market are identical and that they all hire both high-skill and low-skill labor. High-skill labor is always paid above the minimum wage, and lowskill labor is always paid the minimum wage. Therefore, each firm hires an identical share of the minimum-wage labor force and the above-minimum-wage labor force. Note that wage dispersion arises across stores in model 1 but within stores in model 2. Model 3 is our preferred model, where the amount of heterogeneity within and across firms is calibrated using values in table 1 . Model 3 was used to generate the predicted price and employment responses in table 2.

Here it is clear that competitive and monopsony price responses (but not employment responses) are sensitive to assumptions about labor market and worker-type heterogeneity. The competitive price response varies from 0.051 in model 2 to 0.099 in model 1 . Relative to the empirical evidence of a price response of 0.07 , model 1 predicts larger price responses than the evidence and model 2 smaller price responses than the evidence. Consequently, model 1 predicts that some firms must have monopsony power in order to reconcile a large predicted competitive response with a relatively small measured response, but model 2 predicts that over $100 \%$ of all firms are competitive. Therefore, relative to a competitive employment response of $-0.17,{ }^{31}$ model 1 predicts larger employment re-

\footnotetext{
${ }^{31}$ The employment responses do not vary across models only when $\sigma=\eta$.
} 
sponses (in absolute magnitude) and model 2 predicts smaller employment responses.

When we allow for heterogeneity in both worker types and labor markets (model 3), we find that the predicted price response is very close to the empirical estimates, and thus we infer that close to $100 \%$ of all firms are competitive. ${ }^{32}$ As a result, the predicted total employment response is also close to the competitive response. As we argue in the conclusion, the estimates derived from model 3 are within the bounds set by the empirical literature. However, ignoring heterogeneity within or across establishments can badly bias price and employment responses.

To illustrate why aggregation affects the price response, and thus our predicted value of $V$, consider the price response assuming all labor markets are competitive and $\sigma=\eta$ (or alternatively, that all factors can adjust). Recall that competition implies that all labor costs are pushed onto consumers in the form of higher prices. Inserting equation (4) into equation (17) and assuming $V=1$ yields

$$
E\left[\frac{d \ln p}{d \ln w_{\min }}\right]=s_{L} \times \operatorname{Pr}\left(w_{\min } \geq w\left(L^{*}\right)\right) .
$$

Now consider what models 1 and 2 imply for $s_{L}, \operatorname{Pr}\left(w_{\min } \geq w\left(L^{*}\right)\right)$, and thus the predicted price responses. Setting $Z_{-\min } / Z_{\min }=1$, inserting equation (19) into (24) (and noting that there is only one type of labor in model 1 , so $\operatorname{Pr}(L)=1$ and $s_{L}=s_{L}+s_{H}$ ), yields

$$
E\left[\frac{d \ln p}{d \ln w_{\min }}\right]=\left(s_{L}+s_{H}\right) \times \operatorname{Pr}\left(w_{\min }=w_{i}\right) .
$$

Assuming model 2, where all firms are identical and pay some of their workers the minimum wage-and thus $\operatorname{Pr}(L)=\operatorname{Pr}\left(w_{i}=w_{\text {min }}\right)$ and $\operatorname{Pr}\left(w_{\min } \geq w\left(L^{*}\right)\right)=1$-equations (24) and (20) can be rewritten as

$$
\begin{aligned}
& E\left[d \ln p / d \ln w_{\min }\right]= \\
& \qquad\left(s_{L}+s_{H}\right) \times(\text { minimum-wage labor's share of the total wage bill }) .
\end{aligned}
$$

Using equations (25) and (26) and the values in table 3, we can better understand the predicted price responses from models 1 and 2. Since minimum-wage workers are paid less than other workers, $\left(w_{\min }=w_{i}\right)>$ (minimum wage-labor's share of the total wage bill) and thus price passthrough is greater in the first model than the second. The difference arises from the relative weight of high-wage and low-wage workers in the total

${ }^{32}$ Table 2 shows that $V$ ranges from just below one to just above one for reasonable perturbations of the parameters. 
wage bill. For example, in the empirically relevant case where restaurant size and labor's share of the total wage bill are constant across restaurant types, restaurants that hire minimum-wage workers have a smaller payroll and fewer sales. Consequently, for a fixed payroll, this implies more "minimum-wage" restaurants in a labor market and a larger aggregate price response to changes in minimum wage laws.

We now quantify the price predictions of models 1 and 2. Recall that we estimate that roughly $33 \%$ of restaurant workers are affected by the level of the minimum wage, although their compensation consists of only $17 \%$ of the aggregate restaurant wage bill. First consider model 1 . If all restaurants either pay the minimum wage or above the minimum wage, $33 \%$ of all workers are paid the minimum wage by the $33 \%$ of all restaurants that pay the minimum wage. This $33 \%$ of all restaurants has pass-through of $30 \%$ (because labor's share is $30 \%$ ), and the rest have pass-through of $0 \%$, for an aggregate pass-through of $33 \% \times 30 \%=$ $9.9 \%$.

Next, consider model 2. If all restaurants have the same distributions of high-wage and minimum-wage workers, then minimum-wage labor is $17 \%$ of labor costs at every restaurant. If total labor's share is $30 \%$, then we should expect pass-through to be $30 \% \times 17 \%=5.1 \%$ at every restaurant. The large differences between these two calculations makes it clear that properly handling the aggregation issue is critical. Our best assessment, model 3, lies between these two extremes.

\section{Conclusion}

We use a model of labor demand to calibrate the employment response to a change in the minimum wage for the food away from home industry. If all firms are price takers in the labor market, the model predicts roughly a $3.5 \%$ fall in low-skill employment in response to a $10 \%$ increase in the minimum wage. A second implication of the competitive model is that higher labor costs are pushed onto consumers in the form of higher prices. This price response stands in sharp contrast to the monopsony model, offering a way to identify the extent of monopsony power in the labor market for the restaurant industry. Relying on previous research that shows that most of the higher labor costs incurred by employers are pushed onto consumers in the form of higher prices, we infer that few restaurants will have positive employment responses in reaction to a minimum wage increase. Consequently, using the most plausible range of estimates for the key parameters in the model, we find that the low-skill employment response to a $10 \%$ change in the minimum wage is likely to be around $3 \%$. The total employment response, including high-skill (non-minimum-wage) workers is likely to 
be around $2 \%$. These estimates are just slightly below the perfect competition prediction.

Are our findings consistent with studies that directly estimate the employment response to a minimum wage change? Again, we want to emphasize that the findings reported here are for the restaurant industry only. As a result of different intensities of use of minimum-wage labor, substitution possibilities, market structure, and demand for products, other industries should face distinct employment responses. Consequently, it is difficult to compare our results to those that identify the employment effect of the comovement of teenage employment and the minimum wage without knowing the full range of these parameters for the major industry employers of teens.

However, if we were to compare our low-skill results to the teen studies, we believe that our estimates would be well within the range supported in the literature. ${ }^{33}$ Moreover, among those studies that explicitly look at the restaurant industry, our results are quite consistent with Neumark and Wascher (2000), who find the employment response to be around -0.2 but a bit larger than those reported in Card and Krueger (2000). ${ }^{34}$ An employment response of zero, while clearly theoretically plausible, does not seem consistent with the level of monopsony power inferred from the price responses observed in the food away from home sector. Therefore, our results provide evidence against the hypothesis that monopsony power is important for understanding the observed small employment responses in the literature.

\section{Appendix}

\section{The Parameters of the Model}

This appendix details the parameter values we use in the calibration exercise.

\footnotetext{
${ }^{33}$ To get comparable estimates, the teen studies need to be adjusted for coverage (see, e.g., table 2 in Brown [1999]). Brown's adjustments are based on wage distributions for 16-24-year-olds, as calculated in Neumark and Wascher (2002). Brown argues that the share of workers in this age group affected by the minimum wage is close to $20 \%$, suggesting that the elasticity of demand for teenagers should be factored up $1 / 0.2=5$. However, since this calculation is based partly on 20-24year-olds, a more conservative guess for 16-19-year-olds would be 3 .

${ }^{34}$ Our results are not exactly comparable to theirs because our results are for the entire restaurant industry, whereas their results are just for the fast food industry, where a higher share of workers are paid the minimum wage.
} 
Price Pass-Through $\left(E\left[d \ln p / d \ln w_{\min }\right]\right)$

Aaronson et al. (2005) uses store-level data from the Food Away from Home component of the CPI for the period 1995-97 to identify the extent of price pass-through. ${ }^{35}$ They find that, in the aggregate, a $10 \%$ increase in the minimum wage increases prices by roughly $0.7 \%$ during a 4 -month period around the minimum wage enactment date. These results are comparable to Aaronson (2001), which uses panels of U.S. city and Canadian province CPI data from 1978 to 1995. Card and Krueger (1995) also use CPI indexes for Food Away from Home in 27 large metropolitan areas, finding larger price increases in those cities with higher proportions of low-wage workers. Although their estimates are consistent with full passthrough, their standard errors are extremely large. They cannot reject zero price pass-through in many of their specifications. Moreover, additional evidence from specific state increases in Texas and New Jersey suggests close to no price response. As a result, Card and Krueger $(1995,148)$ conclude that their estimates are "too imprecise to reach a more confident assessment about the effects of the minimum wage on restaurant prices." However, Aaronson (2001) and Aaronson et al. (2005) use substantially more data and document large and significant increases in food away from home prices immediately surrounding an increase in the minimum wage. These latter results are consistent with studies of price pass-through resulting from other cost shocks, such as sales taxes levies (e.g., Besley and Rosen 1999) and exchange rate movements (e.g., Yang 1997).

In the calibration exercise, which aggregates all markets and types of restaurants, we use a value for $E\left[d \ln p / d \ln w_{\min }\right]$ of 0.05 or 0.07 .

\section{Labor's Share $\left(s_{L}+s_{H}\right)$}

There are a number of sources for labor share, all of which tend to report similar numbers for the food away from home industry. First, 10$\mathrm{K}$ company reports contain payroll to total expense ratios. Of the 17 restaurant companies that appear in a search of 1995 reports using the SEC's Edgar database, the unconditional mean and median of this measure of labor share is $30 \%$, and it ranges from $21 \%$ to $41 \%$. ${ }^{36}$ These numbers are in line with a sampling of 1995 corporate income tax forms from the

${ }^{35}$ While the time frame is somewhat short, this 3-year period contains an unusual amount of minimum wage activity. A bill signed on August 20, 1996, raised the federal minimum from $\$ 4.25$ to $\$ 5.15$ per hour, with the increase phased in gradually. An initial increase to $\$ 4.75(11.8 \%)$ occurred on October 1, and the final installment $(8.4 \%)$ took effect on September 1, 1997. Moreover, additional variation can be exploited by taking advantage of cross-state differences in market wages, state-imposed minimum wages that exceed federal levels, and differences in establishment type.

${ }^{36}$ The search uses five keywords: restaurant, steak, seafood, hamburger, and chicken. 
Internal Revenue Service's Statistics on Income Bulletin. Because operating costs are broken down by category, it is possible to estimate labor's share. ${ }^{37}$ According to these tax filings, labor cost as a share of operating costs for eating place partnerships is roughly $33 \%$. Consequently, we set $s_{L}+s_{H}$ to $30 \%$ but test the robustness of the results to values between $25 \%$ and $35 \%$.

Finally, we are particularly interested in labor share in low-wage firms. Depending on the elasticity of substitution between factors, firms in highwage labor markets theoretically could have either a higher or lower labor's share. To gauge this heterogeneity, we use the 1997 Economic Census for Accommodations and Food Services, which reports payroll for full-service (FS) and limited-service (LS) restaurants. Since LS include fast-food stores and any restaurant without sit-down service and where customers pay at the counter prior to receiving their meals, they tend to be the primary employer of minimum-wage labor. According to this 1997 census, labor share, as a fraction of sales, is slightly higher at FS (31\%) than LS (25\%) stores. ${ }^{38}$ Therefore, there is little evidence of a significant difference in labor share across establishment type.

Furthermore, there is no evidence of an association between labor share and average city wages. Here, we correlate metropolitan statistical area (MSA)-level labor share from the 1997 Economic Census for Accommodations and Food Services with MSA-level real wage rates computed from the 1990-99 outgoing rotation files of the Current Population Survey (CPS). That correlation is small and statistically insignificant for both limited-service $(-0.08)$ and full-service $(-0.06)$ establishments. The lack of a geographic association between labor share and wages is particularly evident when breaking the cities into quartiles based on their average wage rate during the 1990s. For limited-service establishments, labor share is (lowest to highest wage quartile) $0.258,0.262,0.260$, and 0.256. Among full-service establishments, labor share is $0.308,0.312,0.311$, and 0.306 . See the appendix of Aaronson and French (2006) for further discussion of this point.

\section{Capital and Material's Share $\left(s_{K}\right.$ and $\left.s_{M}\right)$}

Based on the same sample of company financial reports used to compute $s_{L}+s_{H}$, we assume that capital share is $30 \%$ and materials share is $40 \%$. When we allow $s_{L}+s_{H}$ to vary, we also allow either capital or material

${ }^{37}$ The IRS claims that labor cost is notoriously difficult to decompose for corporations, and therefore we restrict our analysis to partnerships, where there is less concern about reporting.

${ }^{38}$ Several $10-\mathrm{K}$ reports of individual restaurant companies show that wages account for $85 \%$ of compensation. Therefore, labor's share based on compensation is roughly $36 \%-29 \%$ at full- and limited-service restaurants. 
share to adjust accordingly. The results are not sensitive to modifications of these shares between capital and materials.

\section{The Share of Minimum-Wage Workers $\left(\operatorname{Pr}\left(w_{\min }=w_{i}\right)\right)$ and Minimum-Wage Labor's Share of the Total Wage Bill}

The minimum wage should affect prices and employment only if it affects wages. Therefore, we need the share of workers' wages influenced by the minimum wage policy. Since this is not available in company reports, we estimate the share of employees who are paid at or very near the minimum wage from the outgoing rotation files of the CPS for the 2 years prior to the 1996 legislation. ${ }^{39}$ During this time period, $23 \%$ of restaurant industry workers were within $10 \%$ of the minimum wage and therefore were clearly affected by a characteristically sized $10 \%$ increase in the minimum wage.

However, this estimate is insufficient for understanding the fraction of workers affected by the minimum wage change. Workers paid slightly above the minimum wage also tend to receive pay increases in response to minimum wage increases. ${ }^{40}$ To approximate this phenomena, we use the outgoing rotation file wage distribution and assume that one-third of workers within $150 \%$ of the old minimum are affected by the new minimum wage change. No one beyond this threshold is assumed to be affected. These assumptions imply $\operatorname{Pr}\left(w_{\min }=w_{i}\right)=0.33$. That is, onethird of restaurant workers are influenced by minimum wage legislation. We test the robustness of the results to values of $\operatorname{Pr}\left(w_{\min }=w_{i}\right)$ between 0.25 and 0.40 .

Using the same CPS data and assumptions about spillovers, we also estimate that minimum wage labor constitutes $17 \%$ of the wage bill. Therefore, $33 \%$ of all restaurant workers are paid the minimum wage, but they are paid only $17 \%$ of the total value of wage payments in the restaurant industry.

\section{The Wage Distribution Parameters $(\operatorname{Pr}(L)$ and wagediff)}

We allow for wage heterogeneity in two dimensions. We assume that there are two types of workers (high skill and low skill) and two types of labor markets (high wage and low wage). We assume that low-skill workers in high-wage markets are always paid above the minimum wage (as are all high-skill workers). However, all low-skill workers in low-

${ }^{39}$ There are no federal changes and only two state changes during these 2 years. We exclude the two states Vermont and Washington with such activity, as well as all data from June to August of 1995, for which there are no geographic identifiers.

${ }^{40}$ See Grossman (1983) and Card and Krueger (1995) for empirical evidence and Card and Krueger (1995), Teulings (2000), and Manning (2003) for potential explanations. 
wage labor markets are paid the minimum wage. Furthermore, we assume that all restaurants have the same skill distribution, so the probability of being low skill, $\operatorname{Pr}(L)$, does not vary by labor market. Given this assumption, $\operatorname{Pr}(L)$ equals the probability that someone in a low-wage labor market is paid the minimum wage. This pins down the probability that a worker is low skill.

We define a local labor market as a city. Aaronson et al. (2005) uses the 1979-95 CPS Outgoing Rotation Groups to estimate the share of restaurant workers that are paid at or near the minimum wage among cities covered in the CPI survey. ${ }^{41}$ That paper finds that roughly $70 \%$ of restaurant workers are paid at or near the minimum wage in the lowestwage cities. Therefore, we assume $\operatorname{Pr}(L)=0.70$ but allow $\operatorname{Pr}(L)$ to vary between 0.60 and 0.80 .

In order to allow for wage differences across labor markets, we set $\theta$ as a two-point distribution. The distribution for $\theta$ shifts wages for both high-skill and low-skill workers, which, in turn, shifts wagediff. We pick wagediff $=1.5$ to match the dispersion in wages across cities. Although the ratio of average wages in high-wage cities (i.e., the highest-paying $50 \%$ of cities represented in the CPI) to average wages in low-wage cities is roughly 1.15, different measures of dispersion give larger differences in high-wage versus low-wage areas. For example, the ratio of wages in the top $15 \%$ of all cities relative to the bottom $15 \%$ of all cities is 1.5 .

Using this information, we can infer the probability that an individual restaurant pays the minimum wage to its low-skill workers using equation (19). Furthermore, we can infer the share of all restaurant workers who work for restaurants that pay the minimum wage using equation (22).

\section{Average Restaurant Size in High-Wage versus Low-Wage Labor Markets $\left(Z_{-\min } / Z_{\min }\right)$}

We compute the average number of employees per restaurant in highwage $\left(Z_{-\min }\right)$ and low-wage $\left(Z_{\min }\right)$ markets using the 1997 Economic Census for Accommodations and Food Services. Our definition of a labor market is an MSA. High and low wage cities are determined by the 19901999 average real wage computed from the Outgoing Rotation Files of the CPS. We combine limited-service and full-service establishments to

${ }^{41}$ The 27 CPI cities are New York City, Philadelphia, Boston, Pittsburgh, Buffalo, Chicago, Detroit, St. Louis, Cleveland, Minneapolis-St. Paul, Milwaukee, Cincinnati, Kansas City, District of Columbia, Dallas, Baltimore, Houston, Atlanta, Miami, Los Angeles, San Francisco, Seattle, San Diego, Portland, Honolulu, Anchorage, and Denver. After 1986, prices for 12 of these cities-Buffalo, Minneapolis-St. Paul, Milwaukee, Cincinnati, Kansas City, Atlanta, San Diego, and Seattle, Portland, Honolulu, Anchorage, and Denver-are reported semiannually. Therefore, they only included pre-1986 observations for those cities. 
compute restaurant size from all restaurants. The results are similar if we look at all eating and drinking places.

We find that restaurants in high-wage cities employ roughly $10 \%$ fewer workers than in low-wage cities. For example, the ratio of restaurant size in the $15 \%$ of cities with the highest wages relative to $15 \%$ of cities with the lowest wages is 0.9 .

Admittedly, there is a great deal of restaurant size heterogeneity within a city. Furthermore, much of this heterogeneity could be because local labor markets are smaller than cities. In order to explore the importance of restaurant size within a city, we measure average restaurant size for full-service (which rarely pay the minimum wage) and limited-service (which often pay the minimum wage) restaurants separately.

We find, on average, that limited-service restaurants employ a little over $20 \%$ fewer workers than full-service restaurants across all cities, $10 \%$ fewer among low-wage cities, and 30\% fewer among high-wage cities. Therefore, using restaurant type, $Z_{-\min } / Z_{\min }$ is, on average, 1.2 , but it varies from 1.1 to 1.3 .

Given the range of estimates for $Z_{-\min } / Z_{\min }$, we set it at one as our benchmark, but we allow it to vary between 0.9 and 1.3 .

\section{The Elasticity of Demand for Food Away from Home $(\eta)$}

There is little compelling evidence on $\eta$ for the restaurant industry. Brown (1990) uses 1977 and 1982 cross-sectional Census data to calculate an $\eta$ of 0.2 and 1 for food away from home and fast food, respectively. Piggott's (2003) estimates, which use time series data and a generalized model of food demand that nests the main demand systems currently in use, suggest more elastic demand, probably above 1. Hussain (2004) uses repeated cross-sectional data from the Consumer Expenditure Survey and carefully controls for some of the endogeneity problems associated with demand estimation. Hussain finds an estimate of $0.2-0.3$ in the basic specification, although he obtains estimates of over one when he addresses the endogeneity of labor supply and durables. In our results, we provide estimates when $\eta$ is between 0.5 and 1.0 .

\section{The Elasticity of Substitution between Labor and Capital $(\sigma)$}

We could not find estimates of $\sigma$ for restaurants. On the one hand, this is unfortunate since there is little reason to expect that factor substitution is equal across industries. In fact, Hamermesh's (1993) review of industryand product-specific $\sigma$ 's reveals a fairly broad range of estimates. However, as Hamermesh stresses, micro-oriented estimates generally do not alter conclusions reached from studies using aggregated data. Substitution between labor and capital is generally between 0.5 and 1.0 for the vast majority of industries, with a mean estimate of 0.75 from Hamermesh's 
review of aggregate studies and 0.50 from his review of micro studies. Given that the overwhelming majority of these studies are based on manufacturing sectors, the closest parallel to the eating and drinking industry that we could find was Goodwin and Brester (1995), which analyzes the food manufacturing industry and which finds that $\sigma$ was roughly 0.9 in the 1970s and 0.5 thereafter. $^{42}$ Therefore, we allow $\sigma$ to vary between 0.5 and 0.8 .

\section{The Marshallian Labor Supply Elasticities $\left(\gamma_{1}\right.$ and $\left.\gamma_{2}\right)$}

We set the labor supply elasticity, holding wages at other firms fixed, at $\gamma_{1}=5$, but we examined the robustness of the results to values between 2 and 10. This range is based on Card and Krueger's $(1995,376)$ interpretation of $\gamma_{1}$ calibrated from estimates of wage elasticities of the hiring and quit functions. Card and Krueger conclude that while $\gamma_{1}$ could vary between 2 and 10, the upper range is more theoretically and empirically plausible.

We set $1 / \gamma(\theta)=1 / 2 \gamma_{1}$, an approximation that is exact if $\theta$ has a uniform density. However, we found all values of $1 / \gamma(\theta) \in\left(0,1 / \gamma_{1}\right)$ to give very similar results.

Bhaskar and To (1999) and Manning (2003) point out that if the labor market is characterized by monopsonistic competition rather than pure monopsony, then setting $\gamma_{1}=\gamma_{2}$ calibrated using hire and quit rates will lead to erroneous inference. Under monopsonistic competition, increases in a firm's wage reduce the quantity of labor supplied at all other firms. Because an increase in a binding minimum wage increases the wage of all firms, it will have a smaller effect on a firm's labor supply than just increasing that firm's wage. Although, for most demographic groups, labor supply elasticities are close to zero, the empirical evidence is that labor supply is somewhat elastic for low-wage groups. Therefore, we set $\gamma_{2}=0.5$ but allow it to vary between zero and one.

\section{References}

Aaronson, Daniel. 2001. Price pass-through and the minimum wage. $\underline{R e-}$ view of Economics and Statistics 83, no. 1:158-69.

Aaronson, Daniel, and Eric French. 2006. Product market evidence on the employment effects of the minimum wage. Unpublished manuscript, Federal Reserve Bank of Chicago. http://www.chicagofed.org/ publications/workingpapers/papers/wp2003_21.pdf.

Aaronson, Daniel, Eric French, and James MacDonald. 2005. The minimum wage, restaurant prices, and labor market structure. Unpublished

${ }^{42}$ Likewise, Hamermesh's review of the substitutability between labor and materials suggests similar-sized values. Again, this is consistent with the findings in Goodwin and Brester (1995). 
manuscript, Federal Reserve Bank of Chicago. http://www.chicagofed .org/publications/workingpapers/papers/wp2004_21.pdf.

Baker, Michael, Dwayne Benjamin, and Shuchita Stanger. 1999. The highs and lows of the minimum wage effect: A time-series cross-section study of the Canadian law. Lournal of Labor Economics 17, no. 2:318-50.

Besley, Timothy, and Harvey Rosen. 1999. Sales taxes and prices: An empirical analysis. National Tax Journal 52, no. 2:157-78.

Bhaskar, V., and Ted To. 1999. Minimum wages for Ronald McDonald monopsonies: A theory of monopsonistic competition. Economic Journal 109, no. 455:190-203.

Brown, Charles. 1999. Minimum wages, employment, and the distribution of income. In Handbook of labor economics, ed. Orley Ashenfelter and David Card. Amsterdam: Elsevier.

Brown, Charles, Curtis Gilroy, and Andrew Kohen. 1982. The effect of the minimum wage on employment and unemployment. Journal of Economic Literature 20, no. 2:487-528.

Brown, Douglas. 1990. The restaurant and fast food race: Who's winning? Southern Economic Iournal 56, no. 4:984-95.

Burdett, Kenneth, and Dale Mortensen. 1998. Wage differentials, employer size, and unemployment. International Economic Review 39, no. 2: 257-73.

Burkhauser, Richard, Kenneth Couch, and David Wittenburg. 2000. A reassessment of the new economics of the minimum wage literature with monthly data from the Current Population Survey. Lournal of Labor Economics 18, no. 4:653-80.

Card, David, and Alan Krueger. 1995. Myth and measurement: The new economics of the minimum wage. Princeton, NJ: Princeton University Press.

- 2000. Minimum wages and employment: A case study of the fastfood industry in New Jersey and Pennsylvania: Reply. American Economic Review 90, no. 5:1397-1420.

Deere, Donald, Kevin M. Murphy, and Finis Welch. 1995. Employment and the 1990-1991 minimum-wage hike. American Economic Review 85, no. 2:232-37.

Dickens, Richard, Stephen Machin, and Alan Manning. 1999. The effects of minimum wages on employment: Theory and evidence from Britain. Lournal of Labor Economics 17, no. 1:1-22.

Dixit, Avinash, and Joseph Stiglitz. 1977. Monopolistic competition and optimum product diversity. American Economic Review 67, no. 3: 297-308.

Fuchs, Victor, Alan Krueger, and James Poterba. 1998. Economists' views about parameters, values, and policies: Survey results in labor and public economics. Journal of Economic Literature 36, no. 3:1387-1425. 
Gilchrist, Simon, and John Williams. 2000. Putty-clay and investment: A business cycle analysis. Lournal of Political Economy 108, no. 5:928-60.

Goodwin, Barry, and Gary Brester. 1995. Structural change in factor demand relationships in the U.S. food and kindred products industry. American Journal of Agricultural Economics 77, no. 1:69-79.

Grossman, Jean. 1983. The impact of the minimum wage on other wages. Lournal of Human Resources 18, no. 3:359-78.

Hamermesh, Daniel. 1993. Labor demand. Princeton, NJ: Princeton University Press.

Hussain, Iftikhar. 2004. Consumer demand and the role of labor supply and durables. Unpublished manuscript, Economics Department, University College London.

Johansen, Leif. 1959. Substitution versus fixed production coefficients in the theory of economic growth: A synthesis. Econometrica 27, no. 2: 157-76.

Karp, Larry, and Jeffrey Perloff. 1989. Estimating market structure and tax incidence: The Japanese television market. Lournal of Industrial Economics 37, no. 3:225-39.

Katz, Lawrence, and Alan Krueger. 1992. The effect of the minimum wage on the fast-food industry. Industrial and Labor Relations Review 46 , no. 1:6-21.

Kim, Taeil, and Lowell Taylor. 1995. The employment effect in retail trade of California's 1988 minimum wage increase. Journal of Business and Economic Statistics 13, no. 2:175-82.

Machin, Stephen, and Alan Manning. 1996. Employment and the introduction of a minimum wage in Britain. Economic Journal 106, no. 436: 667-76.

1997. Minimum wages and economic outcomes in Europe. European Economic Review 41, nos. 3-5:733-42.

Manning, Alan. 1995. How do we know that real wages are too high? Ouarterly Journal of Economics 110, no. 4:1111-25.

- 2003. Monopsony in motion: Imperfect competition in labor markets. Princeton, NJ: Princeton University Press.

Neumark, David, and William Wascher. 1996. Reconciling the evidence on employment effects of minimum wages: A review of our research findings. In The effects of minimum wages on employment, ed. Marvin Kosters. Washington, DC: American Enterprise Institute.

- 2000. Minimum wages and employment: A case study of the fastfood industry in New Jersey and Pennsylvania: Comment. American Economic Review 90, no. 5:1362-96.

. 2002. Do minimum wages fight poverty? Economic Inquirv 40, no. 3:315-33.

- 2003. Minimum wages, labor market institutions, and youth em- 
ployment: A cross-national analysis. Unpublished manuscript, Federal Reserve Board of Governors, Washington, DC.

Piggott, Nicholas. 2003. The nested PIGLOG model: An application to U.S. food demand. American Iournal of Agricultural Economics 85, no. $1: 1-15$.

Rebitzer, James, and Lowell Taylor. 1995. The consequences of minimum wage laws: Some new theoretical ideas. Iournal of Public Economics 56, no. 2:245-55.

Stigler, George. 1946. The economics of minimum wage legislation. American Economic Review 36, no. 3:358-65.

Teulings, Coen. 2000. Aggregation bias in elasticities of substitution and the minimum wage paradox. International Economic Review 41, no. 2: 359-98.

Wellington, Alison. 1991. Effects of the minimum wage on the employment status of youths: An update. Iournal of Human Resources 26, no. 1:27-46.

Yang, Jiawen. 1997. Exchange rate pass-through in U.S. manufacturing. Review of Economics and Statistics 79, no. 1:95-104. 